\title{
ANALYSIS OF MAGNETIC TREATMENT OF PRODUCTION FLUID WITH HIGH CONTENT OF ASPHALT-RESIN-PARAFFIN DEPOSITS
}

\author{
M. Kharchenko ${ }^{1}$, A. Manhura ${ }^{1 *}$, S. Manhura ${ }^{1}$, I. Lartseva ${ }^{1}$ \\ ${ }^{I}$ Department of Oil and Gas Exploitation and Geotechnics, Poltava National Technical Yuri Kondratyuk University, Poltava, Ukraine \\ *Corresponding author: e-mail mangura2000@mail.ru, tel.+380669345503
}

\section{АНАЛІЗ МАГНІТНОЇ ОБРОБКИ СВЕРДЛОВИННОЇ ПРОДУКЦІЇ 3 ВЕЛИКИМ ВМІСТОМ АСФАЛЬТО-СМОЛИСТО-ПАРАФІНОВИХ ВІДКЛАДІВ}

\author{
М. Харченко ${ }^{1}$, А. Мангура ${ }^{1 *}$, C. Мангура ${ }^{1}$, I. Ларцева ${ }^{1}$ \\ ${ }^{1}$ Кафедра видобування нафти і газу та геотехніки, Полтавський національній технічний університет ім. Ю. Кондратюка, \\ Полтава, Україна \\ *Biдповідальний автор: e-mail mangura2000@mail.ru, тел.+380669345503
}

\begin{abstract}
Purpose. Justification of magnetic field application in order to prevent formation of asphalt-resin-paraffin deposits (ARPD) in oil and gas equipment, and consider some current views on the state of ARPD problem in oilfield equipment and possible methods for its solution using magnetic treatment.

Methods. Analysis and generalization of the research results of production fluid magnetic treatment using COMSOL Multiphysics software.

Findings. The technology of magnetic fields application in prevention of asphalt-resin-paraffin deposits is introduced in the article. The obtained results of production fluid magnetic treatment make it possible to use it in oil wells equipped with pumping units, as well as in free flow production method or in wells operated by electric-centrifugal pump, and in oil pipelines.

Originality. The use of high energy magnets based on rare earth materials can reduce asphalt-resin-paraffin deposits in oil equipment.

Practical implications. The proposed magnetic treatment creates opportunities for field exploitation at the later stages of development which are characterized by a high content of asphaltenes, resins and paraffins. The results of production fluid magnetic treatment have proved the efficiency of this technology, which has doubled a turnaround time.
\end{abstract}

Keywords: magnetic treatment, magnetic field, oil, asphalt-resin-paraffin deposits, well

\section{INTRODUCTION}

The current stage of oil industry development in Ukraine is characterized by the following features: reduction of oil production volume, increasing number of inactive and low-debit wells, growth of water cut, scaling and solid inclusions, etc. The topical task of the industry now is to reduce the number of inactive, idle and complicated wells.

It is known that the formation of asphalt-resin-paraffin deposits (ARPD) in economic wells is accompanied by accidents, mainly due to breakages of sucker rods and polished rods, which results in multifiold reduction of their turnaround time (TT) and production volumes.

Different methods are used to control ARPD: the use of scrapers, well treatment by hot oil and water, flushing with distillate, organic solvents, aqueous solutions of surface-active agents (SAA), electric bottom-hole heating, magnetic treatment and inhibition of the production fluid, use of hydrocarbon oxidizing bacteria, etc. (Gavriluk \& Glazkov, 2001).

However, all the known methods of ARPD control are limited depending on conditions of specific fields. For example, biotechnological method, which is limited by high formation pressure and gas factors, high content of hydrogen sulfide in oil and temperatures above $40-50^{\circ} \mathrm{C}$, is recommended for wells operated by rod pumps.

Magnetic treatment has its own requirements to the affected environment, such as gas factor $\left(20-300 \mathrm{~m}^{3} / \mathrm{m}^{3}\right)$, the presence of ferromagnetic particles in well production, the content of asphaltenes and resins no less than the content of paraffin in oil and so on. Electrical methods require quite complex ground equipment for sup- 
plying electricity to underground heating equipment (Chow et al., 2000).

However, the problem of ARPD in the oil fields is topical and needs further improvement of methods for its solution. Research and experience have discovered the advantages and disadvantages of different ways of ARPD control in conditions of specific fields.

Many deposits of Ukraine are characterized by high temperature of oil saturation with paraffin that reaches $48-50^{\circ} \mathrm{C}$. In addition, a typical part of paraffin deposits is ceresin - crystalline high-molecular paraffin, with the number of carbon atoms $36-56$. Ceresins are poorly soluble in oil, and their melting point is $80-92^{\circ} \mathrm{C}$. The corresponding composition of paraffin is presented in Table 1.

Table 1. Homologous composition of paraffins

\begin{tabular}{lcccc}
\hline \multirow{2}{*}{ Components } & \multicolumn{4}{c}{$\begin{array}{c}\text { Mass fractions of components } \\
\text { in the wells of Boryslav OGCF, \% }\end{array}$} \\
\hline Resins & 2.33 & 1.55 & 3.53 & 2.47 \\
Asphaltenes & 2.19 & 3.96 & 5.49 & 2.30 \\
Paraffins & 23.82 & 26.54 & 56.29 & 30.57 \\
Ceresin & 5.00 & 11.00 & 34.00 & 25.00 \\
\hline
\end{tabular}

Ceresin content in the composition of ARPD can be predominant. For example, according to the data in one of the production wells, $70.5 \%$ of the selected sediment mass was ceresin.

According to the industrial observations, it was found that paraffin deposits in production wells of Ukraine decrease with increasing debits of wells and insignificant water content in oil.

There are two known stages of ARPD formation and growth. The first stage is the crystal nucleation and growth of paraffin crystals directly on the contact surface with oil. The second stage - precipitation of larger crystals on the surface covered with paraffin.

The formation of ARPD is significantly affected by the following factors:

- decrease of pressure on the bottom hole and the related hydrodynamic equilibrium of gas-liquid mixture (GLM);

- intensive gassing;

- drop of temperature in the reservoir and borehole;

- changing speed of the GLM and its individual components movement;

- hydrocarbon composition in each phase of the mixture;

- ratio of phases volume;

- condition of the pipes surface.

The intensity of ARPD formation depends on the prevalence of one or more factors that may vary over time and depth, so the number and nature of the deposits are not permanent (Klassen, 1982).

When bottomhole pressure is less than saturation pressure of oil aeration, the system equilibrium is disturbed, which increases the volume of the gas phase, and the liquid phase becomes unstable. This leads to the separation of paraffin not only in the reservoir but also in the well, starting from the bottomhole.

In pumping operating technology, the pressure on the pump sunction may be less than the pressure of oil aeration. This can lead to paraffin deposition in the receiving part of the pump and on the walls of the production string. There are two zones in the tubing above the pump. The first zone is located right above the pump: here the pressure increases dramatically and the saturation pressure also grows. The probability of deposition in this zone is minimal.

The second zone is characterized by the pressure reduction to the level of the saturation pressure and below, where intensive paraffin precipitation starts.

In flow wells, if the pressure in the bottomhole is maintained equal to the saturation pressure, paraffin precipitation can be expected in the tubing string.

It is evident from practice that the main objects in which ARPD are formed are well pumps, tubing, flow lines from wells, reservoirs of gathering stations (Klassen, 1982).

The most intensive paraffin deposition is observed on the inner surface of the tubing. The thickness of sediments gradually increases from the starting point of their formation at the depth of $500-900 \mathrm{~m}$ and reaches a maximum at the depth of $50-200 \mathrm{~m}$ from the wellhead, and then it decreases to the thickness of $1-2 \mathrm{~mm}$ in the wellhead (Fig. 1).

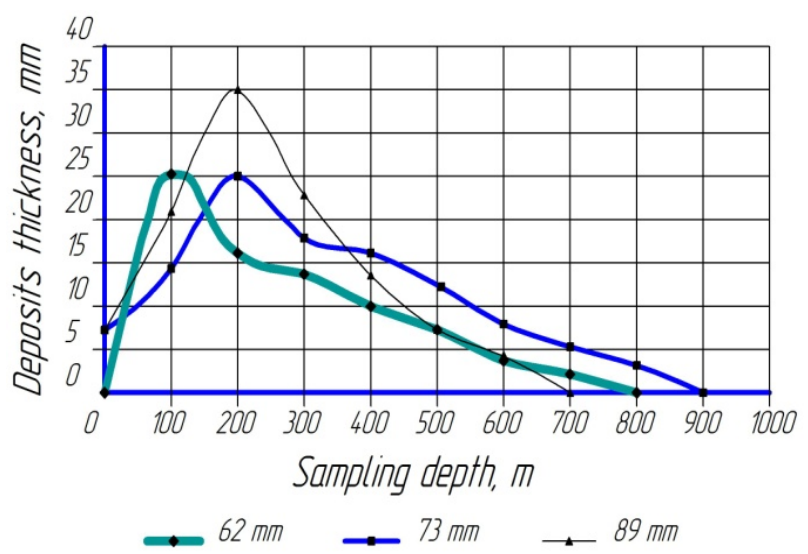

Figure 1. Deposition of ARPD over the well depth

As the depth decreases, the content of asphalt-resins in ARPD also goes down, while the amount of solids and solid paraffins increases (Fig. 2).

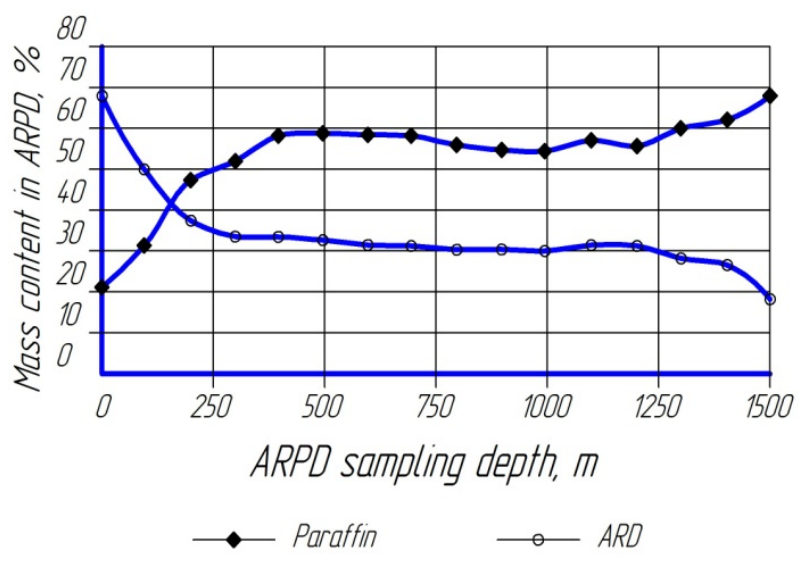

Figure 2. Deposition of ARD and paraffins over the well depth

The closer to the wellhead, the more ceresins are observed in ARPD composition, and, consequently, the higher structural strength of the deposits. 
Oil is a complex mixture in terms of chemical composition. Depending on the structure and the external environment, its components may be in different states of aggregation. Temperature reduction causes change in the physical state of the components, leading to the formation of paraffin crystallization centers and their growth.

Laboratory studies have shown that the rate of paraffins formation has an effect on gas bubbling process and their behavior in the flow of mixture. It is known that gas bubbles have the ability to float suspended particles of paraffin. When bubbles contact with the pipes surface, the paraffin particles come into contact with the wall and deposit on it.

Further, the process of paraffin deposition increases because of its hydrophobicity. A layer of paraffin crystals and gas bubbles is formed on the pipe wall. The less gas saturation of the layer, the greater density it has. Therefore, denser sediments are formed at the bottom of the lifting pipes, where gas bubbles are small and have greater force of adhesion to paraffin crystals and pipe walls.

The intensity of ARPD formation largely depends on the rate of fluid flow. In laminar mode, i.e. at low flow rates, the formation of ARPD is quite slow. With rate increase (during transition to turbulent flow mode), deposition intensity initially increases. Further increase of liquid-gas mixture (LGM) rate leads to decrease in ARPD intensity, as the high rate of fluid flow allows paraffin to keep the crystals in suspension state and carry them out of the well. Furthermore, the moving flow breaks a part of deposits off the pipe walls, which explains the sharp decrease in the amount of deposits in the zone of $0-50 \mathrm{~m}$ from the wellhead. At high rates, the flow of the mixture cools slower than at low ones. In its turn, the ARPD formation slows down at low rates (Pisareva, Kamenchuk, Andreeva, \& Unger, 2005).

The formation of deposits is also affected by the state of pipes surface. Microroughnesses are the sources of vortex formation and layer destruction, they also act as speed retarders near the pipe wall. This is the reason for formation of crystallization centers, sticking of paraffin crystals to the pipe surface, blocking of their movement between the bumps and hollows of the surface.

The process of ARPD formation has an adsorption character. Adsorption processes are accompanied by the appearance of double electric layer on the surface of paraffin contact with gas-oil flow.

In case of mechanical violation of the layer equilibrium on the surface of the pipe or paraffin layer, there appear uncompensated charges of static electricity, in other words electrification takes place on the pipe surface and on the surface of paraffin crystals, which enhances paraffin adhesion to metal.

It is assumed that magnetic fields effect is one of the most advanced physical methods. Magnetic devices were first used to prevent ARPD in the fifties of the last century, but because of its low efficiency this method did not become widespread. In particular, there were no magnets that could work long and steadily in a well.

The period of $1995-2015$ was marked by the renewed interest in the use of magnetic field effect on ARPD, due to the appearance on the market of a wide range of highenergy magnets based on rare earth elements.

\section{THE MAIN PART}

Recently, interest in the use of magnetic fields for treatment of production fluid to prevent ARPD has increased significantly, due to the appearance on the market of a wide range of high-energy magnets based on rare earth materials. It has been found that under the influence of a magnetic field, the moving fluid becomes the media causing the destruction of units comprising submicron ferromagnetic microparticles of iron compounds, with concentration of $10-100 \mathrm{~g} / \mathrm{t}$ in oil and associated water.

Each unit contains from several hundred to several thousands of microparticles, because the destruction of units causes a sharp (100-1000 times) increase in the concentration of paraffins crystallization and formation of micron size gas bubbles on the surface of ferromagnetic particles. As a result of units destruction, paraffin crystals precipitate as finely dispersed, voluminous, stable suspension, and the growth of deposits rate is reduced proportionally to the decrease in average size of fallen paraffin crystals in the solid phase (Zhang, Wang, Wang, \& Zhang, 2015).

Formation of micro gas bubbles in the centers of crystallization after magnetic treatment creates, according to some researchers, the gas-lifting effect, leading to a certain growth of wells production rate. Magnetic treatment of oil, including oil and gas mixtures produced in wells, was intended to prevent (or significantly reduce) the formation ARPD and salts in the tubing and reduction of surface corrosion of pipelines (Tung et al., 2001).

One of the most important results of magnetic treatment is the occurrence of gas micro bubbles formed on the surface of the iron particles. Studies have shown that these micro bubbles have electric charge and high adsorption activity with respect to organic and mineral deposits.

After magnetic treatment, such bubbles provide liquid detergent with properties similar to those that occur when washing powder or soap is added to water. For magnetic treatment effect to manifest in a number of processes, it is necessary to have a combination of several factors. This explains the poor restorability typical for magnetic treatment (Suzuki, Kodera, Matsunaga, \& Kurobe, 1993).

However, the methods of analysis of the substance and hydrodynamic conditions of liquids flow make it possible to create or select technological processes in which industrially important effects consistently appear. It is possible to predict the expected effects in each case, and to prove from a physical point of view the effects already observed.

The effect of magnetic field on the formation of paraffin deposits in the lab helped to solve several problems in the selection of permanent magnets for this or that well in a particular field.

The test which indicates the presence of ferromagnetic particles - the first crystals seeds of ARPD - in borehole production by filtration of oils, can prove reasonability of magnetic field processing of the product. The study of rheological behavior of oils after magnetic treatment allowed to conclude that magnetic field influences their properties different ways (Table 2). 
Table 2. Rheological parameters of oil before and after magnetic treatment at Boryslasv OGCF

\begin{tabular}{lccc}
\hline \multicolumn{1}{c}{ Oil } & $\eta, \mathrm{MPa} \cdot \mathrm{s}$ & $\tau_{c}, \mathrm{~Pa}$ & $E_{a c t}, \mathrm{~kJ} / \mathrm{mole}$ \\
\hline $\begin{array}{l}\text { Before magnetic } \\
\text { treatment }\end{array}$ & 778.1 & 303.2 & 12.84 \\
$\begin{array}{l}\text { After magnetic } \\
\text { treatment }\end{array}$ & 605.0 & 267.3 & 8.21 \\
\hline
\end{tabular}

Decrease of the following oil rheological characteristics has been observed - dynamic viscosity $\eta$ by $28 \%$, boundary shearing stress $\tau_{c}$ by $13 \%$, the activation energy of viscous flow $E_{a c t}$ by $56 \%$ (Nalivaiko, Mangura, Mangura, \& Nalivaiko, 2015).

For the case of a sufficient content of asphalt-resinous substances and trace iron in the borehole fluid, the laboratory analysis of static magnetic field effect on the fliud makes it possible to determine the exact magnetic field topology and intensity, as well as the desired temperature for effective operation of the tool determining the previous installation depth of the magnetic device.

The magnetic device is convenient in operation because it does not require maintenance and supply of any kind of energy. It is most effective to use magnetic devices immediately after well cleanup from existing deposits (Zhang, Wang, Li, \& Zhang, 2013).

Magnetic device for ARPD control is installed on the tubing string. Production fluid stream that passes through the activator is subjected to the influence of strong magnetic fields of permanent magnets, which prevents the formation of asphaltenes, resins, paraffins and salts deposits on the inner surface of the tubing (Ivakhnenko, 2006).

It is considered that the use of magnetic devices can increase the production of wells during overhaul period by $2-5$ times, leading to considerable economy and increase in oil production.

The magnetic device is convenient in operation because it does not require maintenance and supply of any kind of energy. The most effective is the use of magnetic devices immediately after well cleanup from existing deposits.

Magnetic fluid magnetizing device consists of a pipeline casing with a soft magnetic material and the magnetic system fixed to the axis of casing. This system comprises permanent magnets with sequential magnetization directions successively installed along the pipeline casing. These permanent magnets with a circular shape and radial magnetization are placed on the magnetic circuit. On the outer surfaces of permanent magnets are fixed pole pieces, and magnets are placed between the pads of a nonmagnetic material (Das, 2008).

The outer surface of the magnetic system with nonmagnetic spacers between the magnets and pole pieces placed on permanent magnets shaped like a cylinder and as a working channel for the treated liquid is the annular gap crossing between the magnet system and the pipeline casing. Figure 3 shows a diagram of the installation of a magnetic device in the well.

Magnetic device is a body of ferromagnetic pipe. A sleeve joint for tubing is fixed at one end of the pipe. On the inner surface of the casing permanent magnets are fixed.

The device is installed in the tubing string below the bottom-hole pump or in the necessary part of the tubing string. As the mining fluid flows through the casing, it is treated by magnetic field.

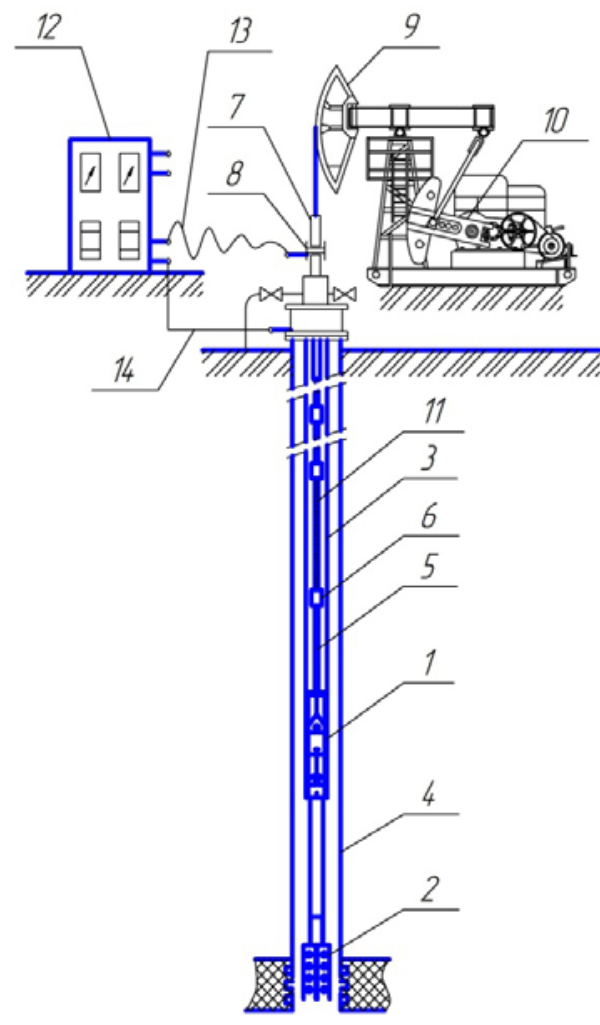

Figure 3. ARPD control technology in the producing wells equipped with sucker-rod pumping unit: 1 -deep pump; 2-magnetic device; 3-tubing string; 4 - column casing; 5 - column rod (steel); 6 - centrators-protectors; 7-polished rod; 8-insulating insert; 9 -balance; 10 -drive unit; 11 -fiberglass rod; 12 -station of cathodic protection (power supply); 13 - cable (flexible); 14 - cable

Some characteristics of the magnetic device:

- the diameter of the device, $\mathrm{mm}-73$;

- lifetime, years, not less than 30 ;

- performance - explosion-protected;

- working pressure, $\mathrm{MPa}$ - up to 15 ;

- weight of the magnetic device, $\mathrm{kg}$ - not more than 10 ;

- operating temperature range of production fluid $10-120^{\circ} \mathrm{C}$;

- production fluid composition which guarantees the efficiency of the magnetic device - watering at least $25 \%$, mineralization at least $150 \mathrm{~g} / \mathrm{kg}$ (Nalivaiko, Mangura, Mangura, \& Nalivaiko, 2015).

The use of the magnetic device doubled the average turnaround time of wells complicated by the formation of emulsions and ARPD. Chemical treatment of the wells was stopped.

At Boryslav OGCR, the use of the magnetic device allowed to increase the turnaround period of wells by 2.2 times and to decrease the number of thermal and chemical treatments, respectively, by 2 and 5 times.

The use of the magnetic device in wells complicated by ARPD allowed to increase their average turnaround time by 2 times and to terminate chemical treatments of wells. Magnetic treatment is aimed to increase turnaround period of wells by directional magnetic field effect (Nalivaiko, Mangura, Mangura, \& Nalivaiko, 2015).

The use of magnetic treatment can be effective, both in the case of well flowing, and its operation by the depth- 
rod, centrifugal and diaphragm pumps as well as on oil pipelines to increase their anti-corrosion resistance.

The payoff period for magnetic devices used to prevent the ARPD formation depending on the turnaround period and geological characteristics of a particular well ranges from one to three months (Wang \& Wang, 2014).

\section{CONCLUSIONS}

The article aimed to describe magnetic treatment of production fluid as a method of ARPD control. The magnetic device runs into the well and this ensures the effectiveness of magnetic treatment of the whole volume of the liquid that passes through the device in the same conditions of high-gradient field with sufficient duration of treatment.

Magnetic treatment differs from other methods of fluid treatment in that this operation does not require any power supply to the unit, because it is based on permanent magnets.

Magnetic Anti-Paraffin Device can work in large diameter pipelines, thus providing the necessary magnetic field and magnetic induction. Therefore, in our opinion, it should be used in the wells with high content of ARPD deposits.

\section{ACKNOWLEDGEMENTS}

The present study would have been impossible without support from Poltava National Technical Yuri Kondratyuk University administration. We express our sincere gratitude for the opportunity to conduct tests in modern Laboratory of Oil and Gas Technologies.

\section{REFERENCES}

Chow, R., Sawatzky, R., Henry, D., Babchin, A., Wang, Y., Cherney, L., \& Humphreys, R. (2000). Precipitation of Wax from Crude Oil Under the Influence of a Magnetic Field. Journal of Canadian Petroleum Technology, 39(06). https://doi.org/10.2118/00-06-05

Das, S.K. (2008). Electro Magnetic Heating in Viscous Oil Reservoir. In International Thermal Operations and Heavy Oil Symposium (pp. 11). Calgary: Society of Petroleum Engineers.

https://doi.org/10.2118/117693-ms
Gavriluk, O.V., \& Glazkov, O.V. (2001). The Application of Magnetic Liquide Treatment in Oil Fields of West Siberia. In 11th European Symposium on Improved Oil Recovery. European Association of Geoscientists \& Engineers. https://doi.org/10.3997/2214-4609.201405977

Ivakhnenko, O.P. (2006) Magnetic Analysis of Petroleum Reservoir Fluids, Matrix Mineral Assemblages and Fluid-Rock Interactions. Ph.D. Institute of Petroleum Engineering.

Klassen, V.I. (1982). Omagnichevanie vodnykh sistem. Moskva: Khimiya.

Nalivaiko, O., Mangura, A., Mangura, S., \& Nalivaiko, L. (2015). Peculiarities of Magnetic Anti-Paraffin Device (MAD) Modeling in COMSOL Multiphysics Software. Problems of Energy Saving and Nature Use, 58-67.

Pisareva, S.I., Kamenchuk, Y.A., Andreeva, L.N., \& Unger, F.G. (2005). The Nature of Formation and Dissolution of Asphalt-Resin-Wax Deposits. Chemistry and Technology of Fuels and Oils, 41(6), 480-485. https://doi.org/10.1007/s10553-006-0013-3

Suzuki, H., Kodera, S., Matsunaga, H., \& Kurobe, T. (1993). Study on Magnetic Field-Assisted Polishing (2nd Report) Effect of Magnetic Field Distribution on Removal Distribution. Journal of the Japan Society for Precision Engineering, 59(11), 1833-1838. https://doi.org/10.1016/0141-6359(94)90185-6

Tung, N.P., Van Vuong, N., Long, B.Q.K., Vinh, N.Q., Hung, P.V., Hue, V.T., \& Hoe, L.D. (2001). Studying the Mechanism of Magnetic Field Influence on Paraffin Crude Oil Viscosity and Wax Deposition Reductions. In SPE Asia Pacific Oil and Gas Conference and Exhibition (pp.7). Jakarta: Society of Petroleum Engineers. https://doi.org/10.2118/68749-ms

Wang, L.J., \& Wang, W. (2014). Paraffin Depositing Mechanism and Prediction Methods of Paraffin Removal Cycle. Applied Mechanics and Materials, (675-677), 1512-1516. https://doi.org/10.4028/www.scientific.net/amm.675-677.1512

Zhang, W.W., Wang, T.T., Li, X., \& Zhang, S.C. (2013). The Effect of Magnetic Field on the Deposition of Paraffin Wax on the Oil Pipe. Advanced Materials Research, (788), 719-722.

https://doi.org/10.4028/www.scientific.net/amr.788.719

Zhang, W.W., Wang, D.D., Wang, T.T., \& Zhang, S.C. (2015). Study on the Mechanism of Magnetic Paraffin Control of Crude Oil Based on the Reorientation of Paraffin Crystals Induced by Magnetic Field. Applied Mechanics and Materials, (743), 137-141.

https://doi.org/10.4028/www.scientific.net/amm.743.137

\section{ABSTRACT (IN UKRAINIAN)}

Мета. Обгрунтувати використання магнітного поля для запобігання асфальтосмолистопарафінових відкладень на нафтогазовому обладнанні, а також розглянути сучасні погляди на стан проблеми асфальтосмолистопарафінових відкладень на нафтопромисловому обладнанні та можливі методи іiі вирішення за допомогою магнітної обробки.

Методика. Аналіз та узагальнення результатів комплексу досліджень магнітної обробки свердловинної продукції за допомогою використання програми COMSOL Multiphysics.

Результати. Запропоновано технологію використання магнітного поля для запобігання асфальтосмолистопарафінових відкладень. Отримані результати використання магнітної обробки свердловинної продукції дають можливість використовувати іiі у нафтопромисловій практиці як у свердловинах, які обладнанні штанговими свердловинними насосними установками, так і при експлуатації свердловин фонтанним способом або свердловин, що експлуатуються електровідцентровими насосами, а також на нафтопроводах.

Наукова новизна. Використання високоенергетичних магнітів на основі рідкоземельних матеріалів, дозволяс зменшити асфальтосмолистопарафінові відклади на нафтовому обладнанні. 
Практична значимість. Запропонована магнітна обробка свердловинної продукції створює важливі передумови експлуатації родовищ, які знаходяться на пізніх стадії розробки та характеризуються великим вмістом асфальтенів, смол та парафінів. Результати проведення магнітної обробки свердловинної продукції довели ефективність використання даної обробки, що призвело до збільшення міжремонтного періоду у два рази.

Ключові слова: магнітна обробка, магнітне поле, нафта, асфальтосмолистопарафінові відкладення, свердловина

\section{ABSTRACT (IN RUSSIAN)}

Цель. Обосновать использование магнитного поля для предотвращения асфальтосмолистопарафиновых отложений на нефтегазовом оборудовании, а также рассмотреть современные взгляды на состояние проблемы асфальтосмолистопарафинових отложений на нефтепромысловом оборудовании и возможные методы ее решения с помощью магнитной обработки.

Методика. Анализ и обобщение результатов комплекса исследований магнитной обработки скважинной продукции с помощью использования программы COMSOL Multiphysics.

Результаты. Предложена технология использования магнитного поля для предотвращения асфальтосмолистопарафиновых отложений. Полученные результаты использования магнитной обработки скважинной продукции, дают возможность использовать ее в нефтепромысловой практике как в скважинах, оборудованных штанговыми скважинными насосными установками, так и при эксплуатации скважин фонтанным способом или скважин, эксплуатируемых электроценторобежными насосами, а также на нефтепроводах.

Научная новизна. Использование высокоэнергетических магнитов на основе редкоземельных материалов позволяет уменьшить асфальтосмолистопарафиновые отложения на нефтяном оборудовании.

Практическая значимость. Предложенная магнитная обработка скважинной продукции создает важные предпосылки эксплуатации месторождений, которые находятся на поздней стадии разработки и характеризуются большим содержанием асфальтенов, смол и парафинов. Результаты проведения магнитной обработки скважинной продукции доказали эффективность использования данной обработки, что привело к увеличению межремонтного периода в два раза.

Ключевые слова: магнитная обработка, магнитное поле, нефть, асфальтосмолистопарафиновые отложения, скважина

\section{ARTICLE INFO}

Received: 2 February 2017

Accepted: 11 May 2017

Available online: 30 June 2017

\section{ABOUT AUTHORS}

Maksym Kharchenko, Candidate of Technical Sciences, Associate Professor of the Department of Oil and Gas Exploitation and Geotechnics, Poltava National Technical Yuri Kondratyuk University, 24 Pershotravnevyi Ave., 1/110, 36011, Poltava, Ukraine. E-mail: maksym.kharchenko@alma.pl.ua

Andrii Manhura, Senior Instructor of the Department of Oil and Gas Exploitation and Geotechnics, Poltava National Technical Yuri Kondratyuk University, 24 Pershotravnevyi Ave., 1/110, 36011, Poltava, Ukraine. E-mail: mangura2000@mail.ru

Svitlana Manhura, Senior Instructor of the Department of Oil and Gas Exploitation and Geotechnics, Poltava National Technical Yuri Kondratyuk University, 24 Pershotravnevyi Ave., 1/110, 36011, Poltava, Ukraine. E-mail: svet-mangura@mail.ru

Iryna Lartseva, Candidate of Technical Sciences, Associate Professor of the Department of Oil and Gas Exploitation and Geotechnics, Poltava National Technical Yuri Kondratyuk University, 24 Pershotravnevyi Ave., 1/110, 36011, Poltava, Ukraine. E-mail: larchik.84@mail.ru 